University of Rhode Island

DigitalCommons@URI

The Rhode Island Current Conditions Index

Economics

7-2014

\title{
Rhode Island Current Conditions Index - July 2014
}

Leonard Lardaro

University of Rhode Island, lardaro@uri.edu

Follow this and additional works at: https://digitalcommons.uri.edu/ricci

Part of the Econometrics Commons

Terms of Use

All rights reserved under copyright.

\section{Recommended Citation}

Lardaro, Leonard, "Rhode Island Current Conditions Index -- July 2014" (2014). The Rhode Island Current Conditions Index. Paper 116.

https://digitalcommons.uri.edu/ricci/116

This Article is brought to you for free and open access by the Economics at DigitalCommons@URI. It has been accepted for inclusion in The Rhode Island Current Conditions Index by an authorized administrator of DigitalCommons@URI.For more information, please contact digitalcommons-group@uri.edu. 


\title{
CURRENT CONDITIONS
}

LEONARD LARDARO, URI

\author{
Available Online: http:/ / www .Ilardaro.com/ current.htm \\ Blog: http:/ / rieconomy.blogspot.com
}

VOL XXI

NUMBER 8

JUL 2014

As Rhode Island moves into the third quarter, it appears to have left the disappointing performance from the prior quarter behind at least for now. The July Current Conditions Index jumped from its neutral value of 50 in June all the way to 75 for July, as nine of the twelve $\mathrm{CCl}$ indicators improved. Not only does this improvement come as welcome news for Rhode Island, the increase from June was somewhat expected. I noted last month that the two $\mathrm{CCl}$ indicators whose performance put a "nail in the coffin" for June's CCl, Benefit Exhaustions and New Claims, had displayed bizarre increases that month that were not explainable by any of the obvious undercurrents in our state's economy. As expected (with my fingers crossed), both went from double-digit rises last month (remember we want both of these to decline) to double-digit declines. So, while it is still accurate at this point to say that Rhode Island's overall performance in 2014 has been disappointing, the July $\mathrm{CCl}$ provides us with a potential glimmer of hope that perhaps things here are beginning to strengthen after all as we move through the second half of 2014 . Before we get carried away, it must be noted that this July's CCl reading of 75 while a marked improvement over June, was still below the

\begin{tabular}{|l|r|r|}
\hline \multicolumn{3}{|c|}{ CCI Indicators - \% Change } \\
\hline Government Employment & -0.7 & \\
\hline US Consumer Sentiment & -4.3 & \\
\hline Single-Unit Permits & 26.3 & Y \\
\hline Retail Sales & 3.3 & Y \\
\hline Employment Services Jobs & 1.2 & Y \\
\hline Priv. Serv-Prod Employment & 2.1 & Y \\
\hline Total Manufacturing Hours & 3.6 & Y \\
\hline Manufacturing Wage & -4.3 & \\
\hline Labor Force & 0.5 & Y \\
\hline Benefit Exhaustions & -30.2 & Y \\
\hline New Claims & -17.2 & Y \\
\hline Unemployment Rate (change) & -1.9 & Y \\
\hline \multicolumn{2}{|c|}{ Y = Improved Value } \\
\hline
\end{tabular}

reading for last July, marking the twelfth consecutive month where the $\mathrm{CCl}$ has failed to beat its year-earlier value. I can certainly think of happier one-year anniversaries! So, as Rhode Island moves into the last half of 2014 the most pressing issue continues to be whether Rhode Island's economic performance will ultimately decouple from the accelerating national economy.

In July, four of the five leading indicators contained within the Current Conditions Index improved, most doing so at healthy rates. Single-Unit Permits, which reflect new home construction, turned in a very strong performance for July, rising by 26.3 percent relative to its value last July. Total Manufacturing Hours, which measures strength in our manufacturing sector, rose sharply again in June $(+3.6 \%)$, as both the length of the workweek and manufacturing employment displayed significant increases. Oddly, in spite of such strong and sustained manufacturing momentum, the Manufacturing Wage actually

\begin{abstract}
declined for a fifth consecutive time in July, by 4.3 percent.
\end{abstract}
Two of the leading indicators that failed to improve last month did considerably better in July. New Claims, which is a leading labor market indicator, fell at a double-digit rate $(-17.2 \%)$ after inexplicably rising at a double-digit rate in June, making it more likely that this indicator will resume a downtrend. Employment Service Jobs, which includes temporary employment, and is a prerequisite to employment growth, rose for the first time since last November $(+1.2 \%)$, halting a streak of seven consecutive declines. In spite of this good news for July, I continue to view changes in this indicator somewhat suspiciously. The sole leading indicator that failed to improve this month was US Consumer Sentiment, which declined for the third consecutive month $(-4.3 \%)$ following a string of five consecutive increases.

Retail Sales remained strong in July, rising by 3.3 percent compared to a year ago. This indicator has now improved for seven of the last nine months. Private Service-Producing Employment rose by 2.1 percent in July, its strongest rate of growth in over a year. As has been the case for quite some time now, Government Employment fell once again, declining in July by 0.7 percent versus a year ago. Benefit Exhaustions, which reflects longer-term unemployment, reversed its strange doubledigit increase of last month, falling by 30.2 percent relative to a year ago. July was the third double-digit improvement for this indicator in the last four months.

Finally, Rhode Island's Labor Force rose by 0.5 percent versus a year ago in July, the same rate as for June. Along with this, our state's Unemployment Rate fell to 7.7 percent, moving us to the highly coveted status of \#3 nationally.

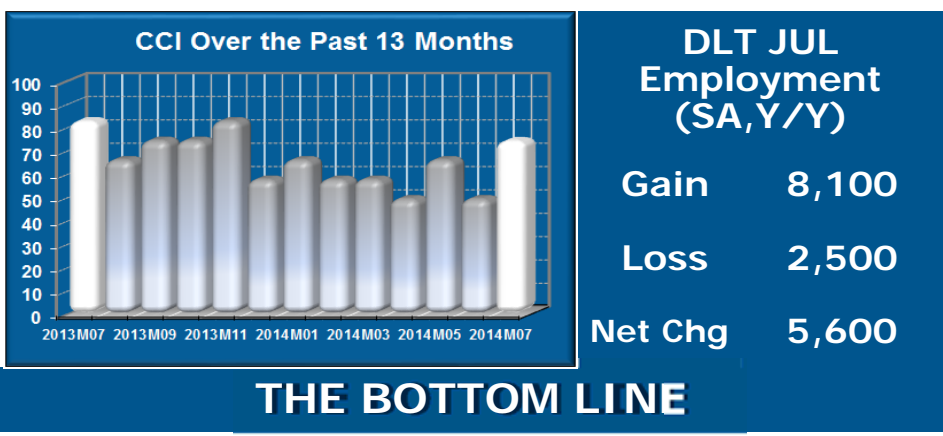

Based on the July $\mathrm{CCl}$, the recent neutral values we observed may well prove to be aberrations. While it is too early to tell for certain at this point, it might be useful to invoke our state's motto: Hope.

Consistently beating prior-year performance will not only require that we sustain much of the momentum displayed this month, but it will be necessary to see improving Consumer Sentiment, which is likely, along with the resumption of a rising Manufacturing Wage, which may be less likely. Don't expect to see improving Government Employment any time soon.

\begin{tabular}{|c|c|c|c|c|c|c|c|c|c|c|c|c|c|}
\hline & & Jan & Feb & Mar & Apr & May & $J$ un & J ul & Aug & Sep & Oct & Nov & Dec \\
\hline & 2013 & 75 & 67 & 83 & $83 \uparrow$ & 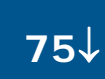 & $83 \uparrow$ & 83 & 67 & $75 \uparrow$ & 75 & $83 \uparrow$ & $58 \downarrow$ \\
\hline & 2014 & $67 \downarrow$ & 58 & 58 & $50 \downarrow$ & 67 & 50 & 75 & & & & & \\
\hline
\end{tabular}

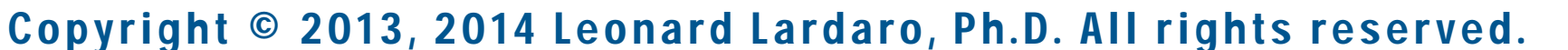

